\title{
Absent Others: Asian-Australian Discontinuities in Michelle de Kretser's The Lost Dog
}

\section{Marie Herbillon}

\section{(2) OpenEdition \\ 1 Journals}

Electronic version

URL: https://journals.openedition.org/ces/388

DOI: $10.4000 /$ ces.388

ISSN: 2534-6695

Publisher

SEPC (Société d'études des pays du Commonwealth)

\section{Printed version}

Date of publication: 30 November 2018

Number of pages: 43-52

ISSN: 2270-0633

\section{Electronic reference}

Marie Herbillon, "Absent Others: Asian-Australian Discontinuities in Michelle de Kretser's The Lost Dog", Commonwealth Essays and Studies [Online], 41.1 | 2018, Online since 05 November 2019, connection on 29 August 2021. URL: http://journals.openedition.org/ces/388; DOI: https://doi.org/10.4000/ces. 388

\section{cc) () $९$}

Commonwealth Essays and Studies is licensed under a Licence Creative Commons Attribution - Pas d'Utilisation Commerciale - Pas de Modification 4.0 International. 


\section{Absent Others: \\ Asian-Australian Discontinuities in Michelle de Kretser's The Lost Dog}

This article relies on the tropes of trauma and gothic haunting to examine Michelle de Kretser's The Lost Dog (2007), in which the protagonist's discarded Indianness allegorically parallels Australia's unwillingness to confront the ghosts of its past. As the novel and its critique of settler culture seem to suggest, the Australian nation should arguably develop alternative cultural paradigms that seek to accommodate both otherness and the most unwelcome aspects of its history, instead of repressing them.

As of times predating its European settlement in 1788, the Australian land was constructed, in the Western world, as an abstract, empty space. Yet, the process by which Australia became a figment of the European imagination was not a harmless one. The colonial myth of terra nullius, which, first and foremost, legitimised colonisation, had other dire consequences, many of which have persisted to this day. Instead of being conceived as a geographical palimpsest inscribed with multiple temporal layers, the Australian continent has tended to be thought of as a spatial and cultural vacuum - a land bereft of history. Not only has this mythical misconception induced a sense of ontological blankness and cultural belatedness among the descendants of the British colonisers; it has also justified the continued oppression and occultation of Aboriginal populations.

In Australia, where the defamiliarizing return of this repressed history has inevitably affected the processes of identity-formation, such foundational historical obliterations have been strongly interconnected with the Freudian notion of the Uncanny. From the colonial era onwards, a ghostliness that cannot be separated from the trauma of Aboriginal dispossession has informed issues of national identity in a country where "the confidence of rightful possession is absent" (Merrilees 67) or at least fragile (The Lost Dog 225). As convincingly argued by Ken Gelder and Jane Jacobs, who see the doctrine of "terra nullius" as "the founding fantasy of modern Australian nationhood" (1356), the concept of the Uncanny is a valuable tool to approach postcolonial Australia: they note that while the latter is unthinkingly referred to as "a 'settler' nation, [...] the 'uncanny' can remind us that a condition of unsettledness folds into this taken-forgranted mode of occupation" (24), thus rendering "'home' [...] unfamiliar" and giving rise to "the experience [...] of being in place and 'out of place' simultaneously" (23). In other words, the Uncanny, which these critics use "to elaborate a modern Australian condition where what is 'ours' may also be "theirs"' (138), is instrumental in "the unsettlement of one's assumptions" (142) about "the issue of possession" (and, by extension, of belonging), which, in Australia, "is never complete, never entirely settled" (138). In this context, rather than being conceived as a naive, utopian ideal positing that silencing the traumatic spectres of history will make it possible to lay them to rest, "reconciliation" becomes "a policy which intends to bring the nation into contact with the ghosts of its past, restructuring the nation's sense of itself by returning the grim truth of colonisation to the story of Australia's being-in-the-world" (30).

In Gelder and Jacobs's footsteps, numerous scholars have suggested, on the one hand, that this postcolonial identity crisis was still current in Australia and, on the 
other, that it concerns not only the nation's original settlers (and their descendants), but also more recent settlers (not necessarily of European descent). Margaret Merrilees, for example, has pointed out that "settler Australia [was] still searching for a way of belonging in an alien land" (67), while Lyn McCredden has asserted that "post-colonial and diasporic hauntings [...] continue[d] to provoke [...] questions about Australian culture's relationship to elsewhere" (13) - to Asia, in particular.

Such "uncanny unsettlement," which bespeaks "the haunting anxiety of not belonging" (Crouch 102), has unsurprisingly been reflected in Australian literature, not least (though not exclusively) in the late twentieth and early twenty-first centuries. In particular, ghost stories, which Gelder and Jacobs have described as "a marginal [colonial] genre" (30) that has survived to this day, are generally "concerned with the continuity and legitimacy of settlement" (Crouch 102). They appear to "reveal repressed fears about place" (Crouch 94) indicating - in David Crouch's terms - that "occupation is never free of ghostly vicissitudes" (95) in a country like Australia. As Crouch further expounds, the ghosts these stories feature (not always literal ones) "might return the violence of colonialism as an ever-present displacement" (95) insofar as some of them at least "can be read as traces of historical traumas" (94). As for these texts' "haunted sites," they "may appear empty or uninhabited - but they are always more than what they appear to be" (Gelder and Jacobs 31). As this article will show, the iconic Australian bush, with the ranks of shadows that populate it, is, of course, a case in point.

The Lost Dog, published in 2007 by the Sri-Lankan-born writer Michelle de Kretser, whose family relocated to Australia when she was fourteen, is a ghost story of sorts, "a haunted work" (Knight 21) which arguably relies on gothic motifs to deploy the themes of history, displacement and belonging in a contemporary Australian context. For all its mostly realistic nature, the author's third novel is indeed underlain by a ghostliness that possibly points to its allegorical dimension and, more specifically, to both its main character's and Australia's histories of repression. The text can also be said to offer a meditation on the constitution of Australian history and, in particular, on the impact of its lacunae on both the concept of nationhood and the formation of exilic identities in a society where the condition of migrancy of many displaced populations remains quite recent. As opposed to the late-eighteenth- and early-nineteenth-century immigration, subsequent immigration to Australia has indeed led to the development of ever more numerous transnational connections. As a non-white writer, De Kretser has critically pondered these connections in order to determine the extent to which Australia's national imaginary could accommodate the non-European, more precisely Asian, immigrant experience. Can this experience allow non-dominant, i.e. non-Anglo, Australian citizens to develop a sense of national belonging or have these successive waves of migration precluded the creation of a truly multicultural nation? In the (unpublished) $\mathrm{PhD}$ chapter she devotes to The Lost Dog, Lyn Dickens contends that while the novel criticises "the limited range of Australian multiculturalism, [...] which involves the acquisition, conditional inclusion and containment of racial difference" (169), i.e. the continuation of colonial structures, its "multiracial and transcultural qualities" also "create a space $[\ldots]$ that encourages alternative imaginaries and modes of relating to difference" (165). As the same scholar indicates, "it is through [... its main characters] Nelly and Tom's encounters with the modern racial imaginary that most of the novel's interventions take shape" (167). 
Like De Kretser herself, the mixed-race male protagonist, who was born in India to a Eurasian mother (Iris de Souza) and an English father (Arthur Loxley), settles in Australia at the age of fourteen. In his new environment, the young and "dark-skinned" (40) Tom Loxley is soon faced with racial prejudice: identified as one of the "black bastards" (25), he opts for cultural assimilation with a view to shielding himself from further discrimination, thus choosing to repress his Indianness in order "to withstand the humiliations that awaited him in an Australian schoolyard" (40). In later life, he further internalises the quintessential codes and values of his new society. As an academic specialising in literary studies, he embraces the rational, analytical, language-based, distanced and controlled frame of mind that can be regarded as typical of post-Enlightenment Western cultures. While the unfathomability of pictures fascinates him, literature is a "medium" he feels "at home" with: unlike images, which "belong to the world of things" and thus "cannot be contained in language," words and narratives, "for all their shifting play, [...] did not exceed his grasp" (7). As James Ley has pointed out, The Lost Dog, while it "retains interest in the cross-cultural identities of its characters," also "casts its thematic net far wider" by exploring what he has called "the hydra of modernity itself" in contemporary Australia. Tom Loxley's attachment to modernity does seem to point to his quest for a form of archetypal Australianness: when Tom's desire to "lead a modern life" is stressed by the narrator, the latter also underscores that "in that respect he was an exemplary Australian” (145). Significantly, Tom's taste for modernity is indistinguishable from a wish to master his environment through a reliance on the characteristically (post)modern trope of irony. In the narrator's terms,

irony was the trope of mastery: of seeing through, of knowing better. And it was a reflex with Tom. He had invented himself through the study of modern literature, and it had provided him with a mode. To be modern was to be ironic. Among the things he was ashamed of was seeming out of date. (238)

No doubt his shame extends to his elderly, utterly unmodern and unironic mother Iris, who emerges as the most obvious antithesis of his modernity. Portrayed as "a relic," she is the vestigial remnant of a different time, an "archaic" (57) embodiment of her son's discarded Indianness.

However, the deliberate yet irrational attempt to bury one's past (especially a traumatic one) is rarely a harmless process and is likely to result in the untimely return of this repressed history. In this context, the narrator himself notes that "when understanding fails, the consequence is always a haunting" (244). As Tom has just completed, away from the distractions of Melbourne, a book dedicated to the Uncanny in the works of Henry James, his (unnamed) dog literally escapes his control and goes missing in the Australian bush. Arguably, the stray animal epitomises loss at several levels. Not only is it reminiscent of its original owner, Tom's former wife Karen, whose absence was made permanent by the failure of their marriage, but it also hints at the loss of "otherness" (22). It emblematises, in this case, Tom's de facto rejection of his Asian background in the wake of the racial trauma he experiences upon his arrival in Australia. Crucially, we are also made to understand that this trauma based on the dismissal of racial difference, more exactly of a constitutive form of otherness, is shared with his adopted homeland, which he therefore appears to allegorise in this regard. The dog's additional association with childhood can also be construed as being of high symbolic significance. As De Kretser has emphasised in a video interview, Tom Loxley is a character who has "lost his 
childhood" as a consequence of his migration to Australia. Terrified at the prospect of a "terrible future" in a world that would be rendered permanently uncanny by migration, "never entirely alien but riddled with strangeness" (20), he discards his Indian past soon after leaving his homeland and immerses himself in his new environment, although the Australian landscape, which "could only just remember colour" (52), has little to do with "a faultless place," which "for him would always be a green [or India-like] one" (2). His decision to blend in culminates in a "sense of having got away with something" when he moves away from his mother, who was "part of what he was intent on leaving" (164), so as to enter university. Around the age of thirty, however, a perceived "narrowing of his life" results in the "epiphanic" adoption of a dog, whose "wild" core breathes some of the "unruliness" and "grace" of childhood back into his all too "ordered existence" (168). Originally "acquired to please his wife," the animal ends up fulfilling "a need that was his alone" (168), as if it had gained the status of a surrogate child for this man who sees himself as being "childless" (82) by choice (Karen, who later bears two children to a different partner, even finds it natural to have an abortion when she is still married to Tom - see 91-2). The novel's dog, which can thus be said to stand for both Tom's own lost childhood and the child he never had, plays a major part in the narrative's allegorical framework, all the more so since it keeps haunting the protagonist "like a revenant" (141 - see also 68, 99-100, 118, 136 and 217). This ghostly presence indeed keeps on recalling the intrinsic "racial" alterity that the absent creature represents - one that its owner loses, as we have seen, with his Indian childhood and that his allegorical counterpart, namely Australia, has all too often tended to reject. The ways in which the text's allegorical traits allow De Kretser to critically explore the matter of Australian identity and collective consciousness will be expanded in what follows through a reliance on the tropes of trauma and gothic writing.

Clearly, the colonisation and settlement of Australia - depicted in the novel as "a country in which the old ideal of rural solitude had been bought with violence" (119) - can be approached as a traumatic historical occurrence "that was characterised by an in-built inability to understand itself" (Delrez, "Symmetries" 53) - hence the "deep ambivalence" that also "characterised the emergence of trauma studies in Australia," a former penal colony endowed with "an unsavoury propensity for representing white settler citizens as the victims rather than the beneficiaries of conquest" (Delrez, "Ghosts" 195). Indeed, the process of settlement (not least when it results from acts of colonialism) generally implies various types of erasure which can be seen to constitute a multi-layered traumatic experience. This trauma of erasure regards, in the first place, the impact on the indigenous populations of their history and culture's cruel annihilation. Yet, it also affects the settlers themselves, who suffer, on the one hand, a cultural loss in the wake of displacement and are tempted, on the other, to discard the memory of the violent dispossession they inflicted on others. While it is possible to consider that transportation traumatised the early settlers and, by extension, modern-day (non-indigenous) Australians, it is therefore imperative to distinguish between what LaCapra called "perpetrator trauma" (79) and "the trauma of dispossession suffered by the Aborigines" from the time of invasion onwards, for any failure to make this distinction authorises a "discourse about the universality of trauma" which "obfuscates the materiality of exploitation and allows the speaker to achieve legitimacy by proxy, through the pursuit of spiritual equivalence with the victims" (Delrez, "Symmetries" 62 and "Ghosts" 199). 
Since any condition of trauma, as David Lloyd notes, "persists in and as a differential relation of power between the perpetrator and the victim" (214), the mutuality of traumatic suffering needs to be relativized in order to avert this particularly insidious kind of cultural appropriation, which tends to obscure unpalatable historical circumstances. However, "Australian society's contempt for all things out-of-date" (Mirza 9) and inability to accommodate history in general, which mirrors Tom's own "flight into modernity" even as it betrays a land defined by its very antiquity, does not make Australia modern but only turns it into a "childish" (The Lost Dog 116) and spectral place, where even the vegetal metonyms for the landscape are depicted as "tree-ghosts" (101). Ignoring the past, i.e. seeking to erase it or refraining from coping with its consequences, is not an appropriate strategy if one's goal is to evade it (see 117). Instead, it is likely to be merely repressed: what is "estranged from [the psyche]" (Freud 148) through a process Freud (and his disciples) called "repression" is bound to reappear at any point in time and to influence the present in all kinds of ways.

In The Lost Dog, "history," both personal and collective, "becomes," as one of the reviewers observed, "a ghost that is almost more present than the present" (Anon.). Although Australia's landscapes seem "emptied of history" (219), inhabiting them is likened to "living in a house acquired for its clean angles and gleaming appliances; and discovering a bricked-up door at which, faint but insistent, the sound of knocking could be heard" (102), disrupting "the huge Australian silence" (228). In a settler colony where the Aboriginal inhabitants were oppressed and dispossessed by non-indigenous populations who still seem unwilling to come to terms with the ghosts of the past, history is doomed to repeat itself at each new encounter with otherness - and will keep haunting the oppressor until previous traumatic events are properly confronted. In this connection, a scene encapsulating a critique of the country's handling of asylumseekers during the early twenty-first-century migrant crisis provides an illuminating case in point which is not devoid of irony, since white Australians were themselves forced exiles at one point in history:

Buried deep in Australian memories was the knowledge that strangers had once sailed to these shores and destroyed what they found. How could that nightmare be remembered? How could it be unselfishly forgotten? A trauma that had never been laid to rest, it went on disturbing a nation's dream. In the rejection of the latest newcomers, Tom glimpsed the past convulsing like a faulty film. It was a confession coded as denial. (208)

The protagonist, who may not be fully aware of the fact that the rejection of his own foreignness amounts to perpetuating the colonial imaginary, still identifies with the refugees he sees on TV in 2001 (the novel's present time - see 23). Although he is personally tempted to repress these images, "willing them to disappear," he realises that they are "imprinted on his retina" (208) and echo his deep-seated anxieties and persistent sense of exclusion. As Maryam Mirza points out when she comments on Tom's sudden "fear of being ejected from the country" deriving from "the belief that he does not belong in Australia" (7),

the refugee crises of the year 2001 are deeply reminiscent of and rooted in the exclusionary politics that characterized nation-building in Australia over many preceding decades, in particular the injustices perpetrated against Aboriginal peoples but also the Immigration Restriction Act of 1901, which consolidated the "White Australia Policy," effectively prohibiting non-white immigration until its abolition in 1973. (8; see also Meredith and Dyster 210) 
In an article devoted to the "role that Sri Lankan Australian fiction assumes in developing intercultural conversations in Australia as a conduit into national harmony" (560), Chandani Lokugé similarly argues that "although Australian public culture is becoming less Anglocentric and more cosmopolitan [...] in recent years, monoculturalism continues to flourish, inciting racism leading to hostility and violence" (559). In this essay, Lokugé also highlights "De Kretser's scepticism with regard to Australia's well-meant but ineffectual effort to celebrate multiculturalism" (563). In an interview published in the same journal, De Kretser herself - as if in response to Lokugé's points - has stated that "places like Australia have, traditionally, been repositories of hope for migrants," adding that while present-day Australia was very different from the country she "came to in 1972, which was still about 98\% white and largely Anglo Celtic [...; in certain sectors of the community there has been, because of the failure of political leaders, [...] a hardening of hearts to people who are really among the wretched of the earth" (575).

In The Lost Dog, not only do the aforementioned refugees remind Tom that "in Australia he was no longer the child of the house" (227) when it came to migration, but they also fail to divert his attention away from the fact that he equally "feared being labelled waste" (209). This type of abject identification is not exactly a novelty: even before leaving the south Indian town of Mangalore, Tom was portrayed as one of "those whose hybrid faces branded them the leftovers of Empire" (18). Yet, not until the Australian migrant crisis does it seem to grow into a source of fear for the protagonist himself. Being, just like these refugees, "instantly identifiable as foreign matter, [...] he feared expulsion from the body of the nation" (209). Even his former in-laws, as members of an Australian middle class that merely "tolerated Asian immigration while not expecting to encounter it at the altar," did not welcome him as an equal into the body of their family, and it can be surmised that their daughter, as a "product of the usual liberal [...] upbringing," had married Tom - at least partly - to "satisf[y] both her need to rebel and her social conscience" (91). As a matter of fact, the author's emphasis on waste as a way of denouncing a given society's racist and consumerist tendencies recurs in a text that teems with physiological, even scatological metaphors (see Callil). A striking episode, in which Tom's ageing mother Iris "los[es] control of her [failing] body" (54; see also 146) and accidentally defecates on her white, waste-disliking sister-in-law Audrey's carpet, further exemplifies, by literalising it, the novel's insistent association between the notion of human waste and those of foreignness and racial difference.

While the minor tragedy of his pet's disappearance deeply unhinges Tom, it should still be viewed as a mere symptom of a broader personal crisis, which possibly started seven months earlier, when he met the enigmatic Nelly Zhang. His eye-/I-opening encounter with this visual artist characterised by her mixed ancestry, her taste for selfinvention and her urge to emphasise her oriental self, forces him to confront his own lack of "affiliation" in a country where he has "no continuity" (82) with his ancestors but where - as seen previously - he still feels threatened, by virtue of his foreignness, with the spectre of social alienation. Despite the "ease" and "familiarity" (43) Tom tends to experience when he is with Nelly, hers is an often-uncanny presence (see 85, 132-3) that has the power to destabilise Tom's existence by casting an indirect light on the hidden fragility of his relationship with Australia. More than once, she proves able to reactivate parts of Tom's pre-migration past, thereby contributing to the return of his repressed Indian history. For example, she "often uncovered [...] souvenirs of the 
past," so that "Tom was transported to India" (71) and "reminded [...] of childhood" (73). She also operates as a trigger for memory in that she prompts Tom's "rediscovery of images" (109) when the latter had long felt they lay beyond him. While some parts of Nelly's own past also remain obscure (she is, for instance, accused of having played a role in the mysterious disappearance of her husband Felix Atwood), its inescapability is demonstrated by aspects of her current life - Rory, the teenage son she had with Atwood, testifies to the impact of the past on the present. As we will see, her acute awareness of this impact induces her never to shun - either in life or in art - the most violent or unwelcome aspects of the past, knowing only too well that the latter is "not what is over but what we wish to have done with" (264). Like Tom, she is mixed-race and culturally hybrid - a combination of Chinese, English, Scottish and Polish influences and origins - and undergoes racial discrimination on this account, although - as opposed to her future boyfriend Tom - she was born in Australia. Unlike Tom, however, she refuses to allow the whites to define and regulate her "layered" (46) identity. Convinced though she is that those she calls "the Australions," "the ones who think they own the place," "won't let [her]" (44) be one of them, she fiercely resists subduing her racial characteristics. While Tom endeavours, at all costs, "not [...] to appear typically Asian" (73, author's emphasis), for example by keeping himself from bargaining with Australian stallholders, she overperforms her Chineseness, at the risk of letting self-fashioning give way to self-caricature (see 45). Although she is only a "third"- or "fourth"-generation Chinese immigrant in Australia and "the cast of her [...] features" is, therefore, "only vaguely Asiatic,"

she exploited it to the hilt, exaggerating the slant of her eyes with kohl [ $\ldots$ and] powdering her face into an expressionless mask. Stilettos and a slit skirt, and she might have stepped from a Shanghai den. A sashed tunic over wide trousers impersonated a woman warrior. She wore her hair cut blunt across her forehead, and drew attention to what she called her "thick Chinese calves". [...] Sometimes she fastened her hair with chopsticks. (44-5)

Yet, she is also careful to resist all-too-easy categorisation by relying on non-Chinese cultural attributes, such as "a rosary strung with mother-of-pearl" worn "as a necklace" or "a red glass bindi" displayed "on her brow," which turn her into "a category error" (45).

The racial and cultural in-betweenness of this "native yet foreign" (125) figure inevitably unsettles Tom, whose own quest for identity has tended - as we have seen - to disregard his Asian inheritance. The "duplicity" (125) of her art, which combines past and present, heritage and modernity, similarly fascinates him for reasons that the narrator attempts to verbalise. As a visual artist, especially one that is "open to youth and novelty," Nelly is said to "inhabit [...] the modern age, the age of the image, while Tom was marooned in words" (71). Whereas literature is widely recognised as a time-art (and has tended to be viewed as such since Gotthold Ephraim Lessing's Laocoön), images (including Nelly's) are presented as "present-time" (132) cultural phenomena. What a literary academic like Tom usually "miss[es] in images" is "the passage of time" (132), which - by contrast - is made palpable by the process of story-telling. However, Nelly's artistic modernity is far from clear (166) or unambiguous: although she almost denies the ghostly dimension of visual art, arguing (in a conversation with Tom) that "fiction's the spooky thing," "the thing that's not there" (132), her own work is deeply concerned with time. Much like the ghost-stories and uncanny tales of Henry James (the novel's 
main literary ghost - see infra), its "unsolvable enigma" (176) irresistibly appeals to Tom because it is haunted by absence(s), by a past that has vanished, and by the traces it has left: "There were no people in Nelly's scenes" but "they suggested dramas from which the actors had fled" and exhibited "shadows thrown by invisible bodies" (155). In more ways than one, i.e. both thematically and formally, absence has become her hallmark, since "from that lack, Nelly had fashioned a style" (155). Not only are Nelly's (most recent) images peopled with ghosts, but they also have the spectral "quality of apparitions" (154) insofar as they are themselves photographic copies of original paintings. As copies of copies from nature, they are in line with what Roland Barthes named secondary mimesis. The temporal, ghost-like, dimension of photography is now - more than that of painting - largely acknowledged. In Camera Lucida, in which Barthes defines the ontology of photography (as opposed to that of cinematography), he argues that the former produces the very essence of the past, its 'being' - a "testimony" that "bears not on the object but on time" (89). Accordingly, a photograph is a trace, the ghost or "the ectoplasm of what-had-been" (87): it renders an absence present, making it impossible to "deny that the thing has been there" (76). Although photographic images are, as such, largely beyond language, thereby "exceed[ing] analysis" (132), they can thus be described as profoundly historical narratives predicated on an act of memorialization: for the narrator, photography - in itself "a spectral medium [...] tirelessly calling up the past" - is also "a tribute to" and "a memory of painting" (175). What Nelly's pictures memorialize, in the novel, is a double absence: the original painting's absent others mirror the absence of the paintings themselves, which Nelly claims she has destroyed but is rumoured to have stored in order to "make a killing one day" (49). Predictably, then, her photos, which negate "the market's lust for the original, offering an endless multiplicity of likenesses instead" (154, author's emphasis), "tantalised with the promise of something more that was always deferred" (176, author's emphasis).

In other words, the "past" is allowed "entry" into Nelly's photographic "nowscapes" (223), which are "infected by" (and inflected with) "historical memory" (223), in the same way as her daily existence encompasses her racial and cultural inheritance. Unlike Tom Loxley, who wrongly assumes, at first, that "history" is "incompatible with modern life" and vainly attempts to break with tradition (and with his Indian legacy in particular) in order to achieve the "continuity" (207) he hopes for, Nelly ZhangAtwood fully understands "the proximity of history," namely the fact that "the present makes use of what has gone before, feeding on and transforming" an "odorous, unhygienic" past which stubbornly "refus[es] to be disposed of" (146). Although she has "no aptitude for narrative" (243) or literature (the time-art par excellence), she resolutely acknowledges, as a visual artist, the need to embrace the past and "find [...] room for [ghosts]" (250). Her propensity for rescuing and collecting lost objects (a penchant she shares with De Kretser herself - see interview with Greg Bearup) further testifies to "an impulse to salvage what had been marked for oblivion" (111; see also 191). Both these "wild objects" (222, author's emphasis) and her images can definitely be approached as "memento mori of the endless rage for the new" (223).

In fact, Nelly's impact on Tom is so powerfully defamiliarizing that she ultimately acts as a catalyst for change. While Tom "was in the habit of proceeding hesitantly" and his book "had been years in the making" (3), it is his "enabling, untragic muse" (136) who makes it possible for him to complete his Meddlesome Ghosts: Henry James and the Un- 
canny - leaving him with the "impression that he had nailed it all down at last" and that "he owed this small triumph to Nelly" (3) - not only by making her bush house available for a few days, but also by giving him a decisive insight into James's work. It can be argued that Tom had been blind to this crucial aspect of James's writing, which had been eluding him for years, by his very psychological closeness to the well-known author, who can thus be viewed as Tom's alter ego in this regard. In fact, James's "ambition to be a modern writer" (68) led him "to distance himself from the literary past, from old forms like gothic," confining his "fascination with the supernatural" to "ghost stories" (such as The Turn of the Screw) and keeping it "out of the major work" (102). Not until "the end of his long life" did he produce again a gothic tale, entitled "The Jolly Corner," demonstrating at last that modernity and history - represented here by a literary tradition whose ghosts too often symbolise a supposedly outdated "romantic discourse" (68) - need not be mutually exclusive. It is only when Tom understands, thanks to Nelly, that "setting out to reject the past" can but "guarantee you'll never be free of it" (103) and, therefore, that the "psychological realism" of some Jamesian texts "did not banish the conventions of gothic fiction" (Ley), that his own book can finally come into being and, more broadly, that he can contemplate the possibility of a fresh start for himself, one that would nonetheless allow for the accommodation of his own historical legacies.

As a character, Nelly thus largely contributes to conveying the idea that Tom Loxley's allegorical counterpart, namely Australia, should seek to emulate what could be termed an alternative modernity, one that would be irreducible to sheer present-ness since, in Nelly's own words, "nothing dates quicker than now" (34). As the author of The Lost Dog seems to suggest through her sharp critique of settler culture (whose arguable obsession with modernity may, to some extent, have blinded it to some of Australia's darkest historical chapters), the aptly named ghost-continent - one of those "settler nations where there [is, allegedly,] no past" (101) but where "forests" and other national spaces are still "walked by" countless "strangers and ghosts" (123) - should urgently reconsider its history. In this respect, Crouch perceptively contends that "the anxieties of being haunted by a dark past should not be repressed" (101). In his view, "a search for legitimate nonindigenous belonging should not attempt to put to rest the unpleasant ghosts of the past in favour of more soothing spirits. Rather, their unsettling presence should be seen as structuring an ongoing negotiation" in "a constant movement between possession and dispossession" (101), past and present, tradition and modernity. Only a recognition of the historical obliterations that the bush - this ghost-like "site constructed from narratives of disaster" (21) - appears to metaphorize will allow for the development of cultural paradigms that incorporate otherness instead of discarding it.

Marie HerbiLlon University of Liège

\section{Works Cited}

Anon. Review of The Lost Dog, by Michelle de Kretser (14 August 2008). <http://mookseandgripes. com/reviews/2008/08/14/michelle-de-kretsers-the-lost-dog/>. Consulted 18 Jan. 2017.

Barthes, Roland. Camera Lucida. 1981. Trans. Richard Howard. London: Vintage, 1993. Trans. of La Chambre claire. 1980. 
Callit, Carmen. "When a Dog Goes Walkabout." Review of The Lost Dog, by Michelle de Kretser. 27 July 2008. <https://www.theguardian.com/books/2008/jul/27/fiction>. Consulted 18 Jan. 2017.

Crouch, David. "National Hauntings: The Architecture of Australian Ghost Stories." Spectres, Screens, Shadows, Mirrors. Spec. issue of JASAL (2007): 94-105.

De Kretser, Michelle. The Lost Dog. 2007. London: Vintage, 2009.

-. "Interview with Greg Bearup (1 August 2013)." <http://www.theaustralian.com.au/ life/weekend-australian-magazine/michelle-de-kretser-the-collector/news-story/ d92f43d0602401d7a19ba998e8813448>. Consulted 18 Jan. 2017.

-. "Interview with Alexandra Watkins: Tourists, Travellers, Refugees." Journal of Postcolonial Writing 52.5 (2016): 572-80.

-. Video interview available on YouTube. <https://www.youtube.com/watch?v=X11ATMnAkgo>. Consulted 18 Jan. 2017.

Delrez, Marc. "Twisted Ghosts: Settler Envy and Historical Resolution in Andrew McGahan's The White Earth." The Splintered Glass: Facets of Trauma in the Post-Colony and Beyond. Ed. Sonia Baelo-Allué and Dolores Herrero. Amsterdam: Rodopi, 2009. 191-204.

-. "Fearful Symmetries: Trauma and 'Settler Envy' in Contemporary Australian Culture." Miscelánea 42 (2010): 51-65.

Dickens, Lyn. Intervening in the Racial Imaginary: 'Mixed Race' and Resistance in Contemporary Australian Literature. Unpublished PhD. U of Sydney, 2014. < http://hdl.handle.net/2123/11589>. Consulted 12 Dec. 2016.

Freud, Sigmund. “The Uncanny.” 1955. The Uncanny. Trans. and ed. David McLintock. Harmondsworth: Penguin, 2003. 121-62. Trans of "Das Unheimliche." 1919.

Gelder, Ken, and Jane M. Jacobs. Uncanny Australia: Sacredness and Identity in a Postcolonial Nation. Melbourne: Melbourne UP, 1998.

Knight, Stephen. "Bush Hauntings." Times Literary Supplement 2 May 2008, 21.

LACAPrA, Dominick. Writing History, Writing Trauma. Baltimore, MD: Johns Hopkins UP, 2001.

Lessing, Gotthold Ephraim. Laocoön. 1836. London: Dent, 1970. Trans of Laokoon. 1766.

LeY, James. Review of The Lost Dog, by Michelle de Kretser (3 December 2007). <http:/ /www.theage. com.au/news/book-reviews/the-lost-dog/2007/12/03/1196530553312.html>. Consulted 18 Jan. 2017.

LloYD, David. “Colonial Trauma / Postcolonial Recovery?” Interventions: International Journal of Postcolonial Studies 2.2. (2000). 212-28.

Lokugé, Chandani. "Mediating Literary Borders: Sri Lankan Writing in Australia." Journal of Postcolonial Writing 52.5 (2016): 559-71.

McCredden, Lyn. "Haunted Identities and the Possible Futures of 'Aust. Lit."' Spectres, Screens, Shadows, Mirrors. Spec. issue of JASAL (2007): 12-24.

Meredith, David, and Barrie Dyster. Australia in the Global Economy: Continuity and Change. New York: Cambridge UP, 1999.

MerriLees, Margaret. "Circling with Ghosts: The Search for Redemption.” Spectres, Screens, Shadows, Mirrors. Spec. issue of JASAL (2007): 65-76.

Mirza, Maryam. "The Anxiety of Being Australian: Modernity, Consumerism, and Identity Politics in Michelle de Kretser's The Lost Dog." The Journal of Commonwealth Literature. 1 February 2018. $<$ https://journals.sagepub.com/doi/abs/10.1177/0021989418755541>. 